\title{
ABUSIVE TAX SHELTERS \\ An Ethical, Historical, and Legal Analysis
}

EVAN SPEECE

IN RECENT YEARS, THE LINE BETWEEN TAX ADVISORY AND ILLECAL TAX SHELTER SERVICES HAS BECOME INCREASINGLY BLURRED. THE ETHICAL DILEMMAS THAT TAX SHELTERS PRESENT CHALLENGE PROFESSIONALS TO MAINTAIN THEIR INTEGRITY AND OBIECTIVITY. THIS ESSAY EXPLORES TAX SHELTER SERVICES FROM HISTORICAL, LEGAL, AND ETHICAL VIEWPOINTS. IT ALSO EXAMINES LITIGATION, BOTH RECENT AND LONG-STANDING, THAT HAS BLAZED THE PATH FOR THE TAX SHELTER ADVISORY THAT IS CURRENTLY PROVIDED BY BUSINESS PROFESSIONALS. THE DISCUSSION IN THIS PAPER IS ESPECIALLY APROPOS GIVEN THE SPATE OF INTERNATIONAL TAX SHELTER CONTROVERSIES THAT HAVE EMERGED IN THE PAST YEAR. 


\section{NTRODUCTION}

For decades, tax advisory services have represented an integral business segment for public and private accounting firms. Although tax counseling has traditionally been considered a non-attest function, many large and renowned accounting firms regarded tax advisory as an indelibly complementary service to auditing in the early I9oos. Gradually, this philosophy became outmoded as a consequence of the explosive growth in the accounting industry and the divergence of the auditing and tax professions. Presently, auditing and tax advisory are prevalently considered professional services that should be rendered independently. However, the issue of tax shelters blurs these seemingly distinct lines. Furthermore, the "abusive" applications of tax shelters provide many financial incentives that elicit legal and ethical dilemmas for several classes of professionals. Recent litigation highlights the importance of examining these "abusive" tax shelters from a historical, legal, and ethical perspective.

Conceptually, there seems to be an ethical boundary that is either approached or crossed in the design, implementation, and usage of abusive tax shelters. This essay will examine the structural imperfections that engender these ethical quandaries within the context of the modern-day accounting and legal industries. In order to complement this composition's external view of the subject, I interviewed three professionals who have significant experience with the types of tax shelters delineated in this paper. To facilitate a reduction of bias and to provide a more wellrounded internal outlook, two of my interviewees were tax lawyers and one was a tax professional working for a public accounting firm. However, both lawyers are also licensed CPAs who practiced in public accounting before joining their respective law firms. Their opinions and observations are incorporated throughout the paper in order to present an integrated, organic approach to the topic. This examination will conclude with suggestions for further research and a demarcation of possible solutions for the future of abusive tax shelters. The proposed strategies will be founded on an amalgamation of legal and ethical perspec- tives and will elucidate the probable role of the professional in the continually dynamic world of tax shelter activity.

\section{BACKGROUND AND HISTORY}

In its simplest form, a tax shelter is defined as "a strategy, investment, or tax code provision that reduces tax liability." However, this seemingly uncomplicated meaning has evolved dramatically over the past several decades. The national laws that regulate our taxation system and the usage of tax shelters are promulgated through the Internal Revenue Code (IRC). Consequently, the IRS is also responsible for the enforcement of our nation's tax laws. It is important, then, to understand the lens through which the IRS views the usage of tax shelters. Essentially, there are two types of tax shelters available to the general public. First, there are intended tax shelters; this class encompasses uses which were intended by the IRS through the creation of the various tax shelter regulations. An example of an intended tax shelter is a typical $40 \mathrm{I}(\mathrm{k})$ plan. The second group includes all of those uses not intended by legislation. This class of unintended tax shelters includes the focus of this paper, abusive tax shelters. Examples of these transactions will be detailed later in this paper. The IRS officially defines abusive tax shelters as "transactions promoted for the promise of tax benefits with no meaningful

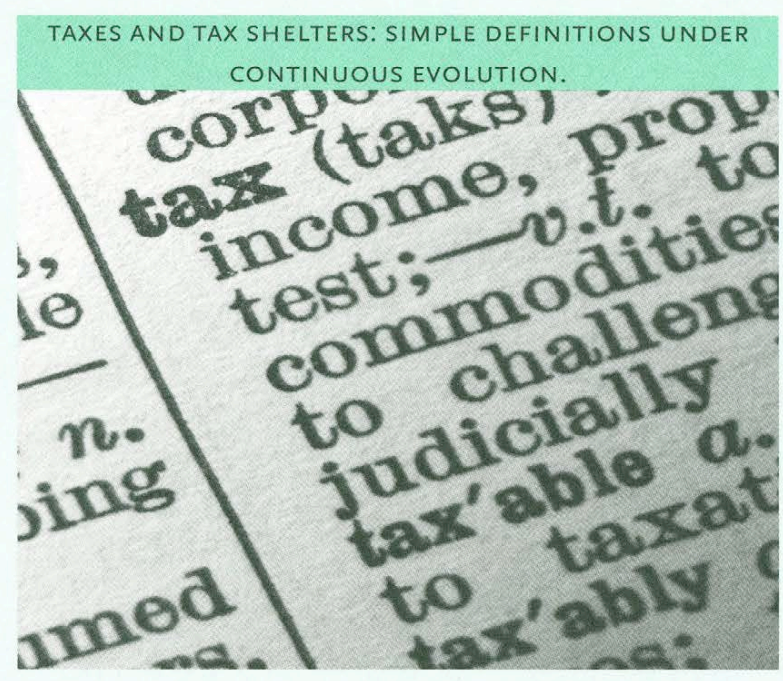


change in a taxpayer's income or assets." ii Thus, the engineering of tax shelters which have no clear economic substance with respect to the taxpayer are regarded as abusive tax shelters. The idea of "transactional economic substance" is a key concept and will be discussed more thoroughly in a later section of this essay.

"... the promulgation of the 'passive loss' rules achieved an unintended effect; the bulk of abusive tax shelter activity shifted to the corporate sphere, where the new regulations did not apply and the tax law is exponentially more intricate."

As tax advisory has become an increasingly important and profitable industry, the amount of legislative scrutiny and political efforts aimed at curbing the usage of abusive tax shelters has also intensified. From the I950s through the I980S, the government attempted to address the issue almost entirely through judicial proceedings and the case law which ensued. Federal courts mainly attempted to erase the economic effects of the abuses and imposed monetary penalties on wrongdoers. ${ }^{\mathrm{iii}}$ However, the government's strategy was largely ineffective, and the number of tax shelter abuses continued to rise. The continued spread of this exploitation necessitated an expedient response. In 1976, Congress passed the Tax Reform Act of 1976. This legislation created certain "at-risk" rules which prohibited taxpayers from claiming losses for investments in which they maintained minimal financial risk. This act was the first substantive response to the rapidly growing usage of abusive tax shelters. The Revenue Act of 1978 and the Economic Recovery Tax Act of 198r both extended the aforementioned "at-risk" regulations to a further extent. Unfortunately, Congress was just beginning to recognize the increasingly popular financial temptation to utilize abusive tax shelters in business transactions.

The year 1984 brought the next landmark in the history of abusive tax shelters. In that year, Congress enacted the Deficit Reduction Act, which aimed to close a number of loopholes in the tax code. Most importantly, this act made it mandatory for taxpayers to register tax shelters with the IRS. iv This requirement was meant to aid the IRS in the location and evaluation of tax shelter activity in the United States. Furthermore, engineers and sellers of "potentially abusive tax shelters" were compelled to retain a list of investors participating in registered tax shelters. Monetary penalties were also strengthened via the Deficit Reduction Act. In the Tax Reform Act of I986, Congress created the "passive loss" rules which have remained important in evaluating the validity of tax shelters to this day. These regulations "prevent an individual (but not a corporation) from claiming a loss from an activity, unless the individual materially participated in the activity."vi However, the promulgation of the "passive loss" rules achieved an unintended effect; the bulk of abusive tax shelter activity shifted to the corporate sphere, where the new regulations did not apply and the tax law is exponentially more intricate. This shift has remained largely unchanged as the majority of abusive tax shelter legislation and enforcement is currently targeted at the corporate and governmental arenas rather than at individual taxpayers.

In 1998, the IRS Restructuring and Reform Act was initiated. Through this act, Congress explicitly directed the 
Joint Committee on Taxation (JCT) and the U.S. Treasury to perform studies examining tax shelter law (current to that time) and interest provisions and then to "make legislative or administrative recommendations." "vii This research was intended to uncover and eliminate the activities of abusive corporate tax shelters. One year later, the two organizations presented the JCT Penalty Studyviii, the JCX 84-99 ix, the Treasury White Paper ${ }^{\mathrm{x}}$, and the Treasury Penalty Study ${ }^{\mathrm{x}}$. Contemporaneously, the IRS effectively "closed" several abusive corporate tax shelters in which numerous corporations and individuals had invested. The IRS established the Office of Tax Shelter Analysis (OTSA) to operate as the governmental stronghold in the fight against abusive tax shelters. Concurrently, the Treasury enacted Circular 230, which recommended regulatory changes to standards of practice for tax professionals that severely impacted the manner by which they advised tax shelter investors.

As one lawyer noted, "2000 was the apex of the government's war on tax shelter abuse." regulations were enacted in a concerted effort to curtail the use of aggressive tax shelters. The most salient of these new rules required corporate taxpayers to disclose investments in certain "reportable transactions" (tax shelters) in their tax returns. xiii Another regulation introduced the mandatory maintenance of lists of those investing in certain corporate tax shelters delineated in IRC Section GIr2. IRS Notices 2000-I5 also distinguished ten different "listed transactions" as examples of abusive tax shelters in order to aid corporations in compliance with the new regulations. In May of 2000 , the IRS issued the Notice of Proposed Rulemaking (NPRM) which amended Circular 230, the foundation for the standards of practice for all tax practitioners before the IRS. xiv The NPRM was an extremely significant piece of legislation as it was a direct warning from the government to all tax professionals. In essence, the NPRM "warn[ed] the law and accounting firms that put together tax shelter transactions, as well as the practitioners and chief financial officers who used them, that their professional reputations and fortunes might suffer if the rules were not followed."xv Thus, the government's attitude and legislative intent was becoming increasingly transparent.

The responses of the respective industries to new tax shelter legislation were consistently and extensively solicited by Congress. The most important of these hearings occurred in June 2000 when official comments were given (under oath) by the AICPA, the Tax Executives Institute, and the Chicago Bar Association. The consolidated response from industry professionals was that the regulations were excessively broad and could possibly lead to the unfair pursuance of individuals and businesses that were conducting legitimate transactions and engaging in legal tax planning. It is not surprising, therefore, that all three of my interviewees believed that the tax shelter legislation currently in place is "sufficiently, if not overly, broad." xvi Clearly, tax practitioners were worried that the government would impinge too heavily upon their business interests.

\section{FORMS OF ABUSE AND CASE LAW H ISTORY}

"Anyone may so arrange his affairs that his taxes shall be as low as possible; he is not bound to choose that pattern which will best pay the Treasury; there is not even a patriotic duty to increase one's taxes."xvii Esteemed Judge Learned Hand famously declared this idea in a I934 judicial ruling. However, in contrast to this opinion, the OECD stated in I998 that "many forms of harmful tax competition are aimed at taxpayers willing to engage in tax evasion ... or tax avoidance. From the perspective of raising revenue and controlling base erosion ... preventing tax avoidance... is as important as curbing tax fraud." xviii These two quotes highlight the tension that permeates the debate over abusive tax shelters. This tension is the manifestation of the ethical boundary which I referenced at the outset of this composition.

Tax shelters garner "abusive" status either through legislation, which identifies a specific transaction as such, or via case-by-case judicial decisions. Usually, abusive tax shelters involve exotic investment schemes which are engineered and are not typical financial strategies. In 
recent years, several landmark cases have altered the legal environment underlying tax shelter transactions. Judges in these cases have continually relied upon the equitable doctrine of "economic substance," which was first utilized in the Supreme Court case of Gregory v. Helvering.xix In one such case, Long-Term Capital Holdings v. United States of America, ${ }^{\mathrm{xx}}$ a corporate taxpayer significantly reduced its tax liability through an outlandish financial arrangement. In the disputed transactions, the lessee, who was organized under British law, attained lease prepayments on subleases. These prepayments were then exchanged for preferred stock of several American corporations. After the lessee gave the preferred stock to certain taxpayers for a partnership interest and then sold its interest back to the taxpayers, the taxpayers sold a large portion of the contributed preferred stock to generate the supposed losses. The court decided that the business deal lacked economic substance and had no business purpose other than tax avoidance. Thus, it had to be set aside for tax purposes. Also importantly, the court imposed substantial fines on the corporation by assessing tax underpayment and gross valuation misstatement penalties. ${ }^{x x i}$

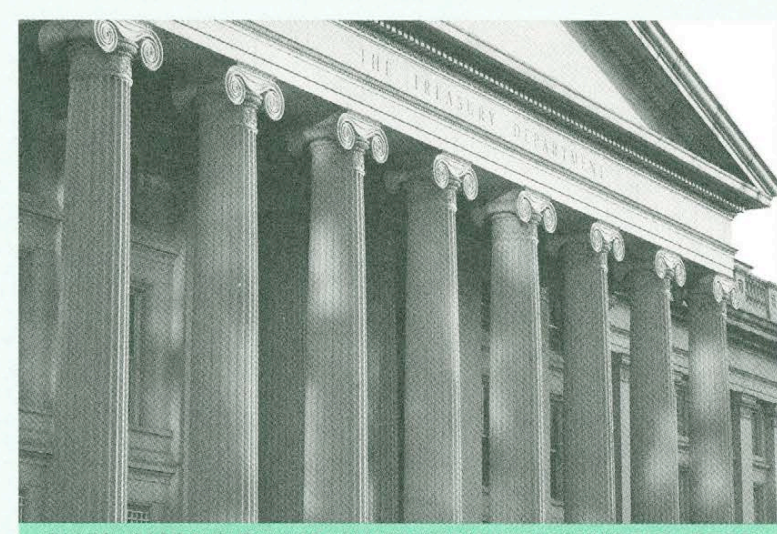

BLIPS, AMONG OTHER INNOVATIVE TAX SHELTERS, COST THE TREASURY \$1.5 BILLION OF UNCOLLECTED REVENUE.
Simultaneously, there was a proposal in Congress to clarify and codify the economic substance doctrine used by so many of our nation's judges. However, the movement was widely criticized and eventually dropped by the House. There is another proposal to codify the economic substance doctrine which is currently circulating through the government. If accepted, the doctrine could further solidify the government's efforts against abusive tax shelters.

Many unintended tax shelters occur through inter-jurisdictional transactions. Myriad international companies have realized that shifting finances, materials, and other intangible assets from a domestic division to a foreign subsidiary division can result in substantial tax savings. In accounting, these types of transactions require the performance of transfer pricing. Without exploring the technical details of the process, transfer pricing is simply the method of setting the price at which a product or service is transferred between two divisions in the same organization. ${ }^{x x i i i}$ The taxation of assets passed through these transfers is extremely complex and thus engenders the possibility for the use of abusive tax shelters. Essentially, companies can

There have been numerous cases that have addressed deals exactly like the one transacted in the Long-Term Capital case. These deals, which primarily involve the contribution of high-basis, low-value assets to a partnership, have been continually struck down by our nation's courts. In response to these monumental judicial proceedings, the government enacted the Jobs Act of 2004. As one article noted, "the provisions [in the Jobs Act] represent the most significant effort by Congress to crack down on tax-motivated transactions since the Tax Reform Act of I986."xxii attain lower tax rates by inflating the value of products, including intangibles such as licenses and trademarks, transferred between a subsidiary and a parent company. The recipient then deducts the cost of the item in its home country to offset profits. Indeed, IRS Commission Mark Everson labeled international transfer pricing "one of the most significant challenges . . . in the area of corporate taxation."xxiv

In the fall of 2003, the Senate Permanent Subcomittee on 
Investigations carried out hearings on the questionable tax shelter activities of KPMG. The investigation eventually uncovered that "from the late I990s into the next decade, KPMG devoted significant resources to developing and mass marketing hundreds of abusive tax shelters." ${ }^{x} \mathrm{v}$ KPMG, which made hundreds of millions of dollars exclusively through its tax shelter business, was one of many large accounting firms accused of marketing abusive tax shelters. The negligent tax shelter activities of Arthur Andersen, PricewaterhouseCoopers, Ernst and Young, and Deloitte were all exposed contemporaneously with KPMG's troubles. Over 30 KPMG partners were criminally indicted and more indictments of former tax partners are incur.xviii KPMG charged clients a contingent fee of 1.25 percent of the tax loss claimed for this product. The product earned KPMG approximately $\$ 53$ million in revenue, but was discontinued when the IRS listed it as an abusive tax shelter in 2002. In sum total, BLIPS is thought to have cost the U.S. Treasury at least \$1.5 billion of uncollected revenue.

If the government hopes to continue to curtail the creation and usage of abusive tax shelters, it must work to elucidate the line between unintended, but legitimate tax shelters and truly abusive tax shelters. As one interviewee noted, "there are many unintended tax shelters which are accepted

\section{"If the government hopes to continue to curtail the creation and usage of abusive tax shelters, it must work to elucidate the line between unintended, but legitimate tax shelters and truly abusive tax shelters."}

likely. ${ }^{x x v i}$ Curiously, it was lawyers at KPMG, rather than accountants, who were the main tax shelter consultants at the firm. This is not surprising, however, given the large influx of lawyers into Big Four accounting firms during the late I990s. Accordingly, both of the lawyers whom I interviewed had worked for Big Four accounting firms within the past decade.xxvii This association between lawyers and accountants in tax work is a microcosm of the tax profession, in which both are positioned to provide tax consulting.

In the late I990s, KPMG and several other firms created "Tax Innovation Centers" through which the firms marketed their innovative tax shelters to potential clients. One such product created by KPMG was BLIPS, or Bond Linked Issue Premium Structure. BLIPS allowed corporate taxpayers to create large deductions resulting from prepayment loan penalties that the corporate taxpayer did not truly throughout the industry and, in some instances, even encouraged by IRS officials."xxix These types of shelters are allowed, but not statutorily set forth. One example of this concept is the use of funding deferred qualification plans in corporate environments. Employee deferred compensation plans and "Rabbi Trusts," which create tax shields through trust arrangements, are both illustrations of these types of shelters. Another prime example of unintended, but legally eligible tax shelters involves the movement of passive income through affiliated entities in different states. For instance, a corporation doing business in Pennsylvania may transfer the passive portion of its income to an affiliated entity in Delaware. This allows the corporation to avoid the Pennsylvania state corporation tax, which is the second highest rate in the nation, and pay the Delaware state corporation tax, which is zero percent. See Container Corp. v. Franchise Tax Board. $x x x$ 
Through adjudication, the Supreme Court has interpreted the law to say that if Congress does not take certain actions to allow states to implement certain tax regulations, then the Commerce Clause set forth in our Constitution should remain dormant. In response, Congress has chosen not to override this principle. Essentially, therefore, if Congress wanted to grant the states more powers in terms of tax legislation and enforcement, it could. However, Congress has chosen to remain silent on the issue, thereby furthering the legitimacy of the use of unintended, un-abusive tax shelters. As one tax professional noted, "Congress passes laws, and reasonable people interpret them." xxxi

\section{THE ROLE OF THE PROFESSIONAI}

The "reasonable people" left to interpret tax shelter legislation, case law, and governmental actions are lawyers and accountants who practice as tax professionals. Those professionals who have continued to use potentially abusive tax shelters have prevalently espoused the "strict constructionist" view. In this outlook, statutes are thought to be susceptible to interpretation. For the most part, case law in our country has reinforced this philosophy. On the downside, one interviewee noted that the continuation of this attitude may lead to courts being overburdened with interpretation of complicated tax rules.xxxii Coupled with the overly litigious nature of our society, this potential imposition could further intensify the debate over abusive tax shelters. The same interviewee has observed that case law is moving in the direction of "smell tests." This type of evaluation, he believes, would create a much more difficult business environment for salesmen who aggressively market abusive tax shelters.

One question that has continually plagued the tax profession is whether accountants or lawyers are better positioned to provide tax shelter advice. Much of this debate centers on the regulatory environment within each profession. Accountants providing tax shelter advice have been severely limited by the passing of the Sarbanes-Oxley Act and the simultaneous creation of the PCAOB. According to the tax professionals whom I interviewed, these events, coupled with the continually intensifying scrutiny of the IRS as well as the SEC and the KPMG proceedings, have caused a significant decrease in the number of accountants marketing and implementing abusive tax shelters.xxxiii Indeed, several public accounting firms are currently working to adopt internal professional standards which will allow their tax professionals to more effectively comply with external regulators. Thus, accountants working with tax shelters have both internal and external pressures to conform to less aggressive tax shelter policies.

In comparison to accounting businesses, law firms are much less regulated. The primary source of regulatory pressure for lawyers is the IRS's enforcement capabilities. Law firms monitor their attorneys' tax shelter work, but to a much lesser extent than their counterparts in accounting firms. Both of my attorney-interviewees, who had worked in public accounting firms before transitioning into the legal arena, confirmed this conclusion. xxxiv Thus, with respect to the professional regulation surrounding tax shelter work, lawyers have much more incentive and less discouragement to push the envelope. This creates a situation where accountants are more likely to be the developers of abusive tax shelters and lawyers the promoters of and consultants for these shelters. Indeed, one of my attorney interviewees termed his job as primarily consulting work rather than legal work. $x x x y$

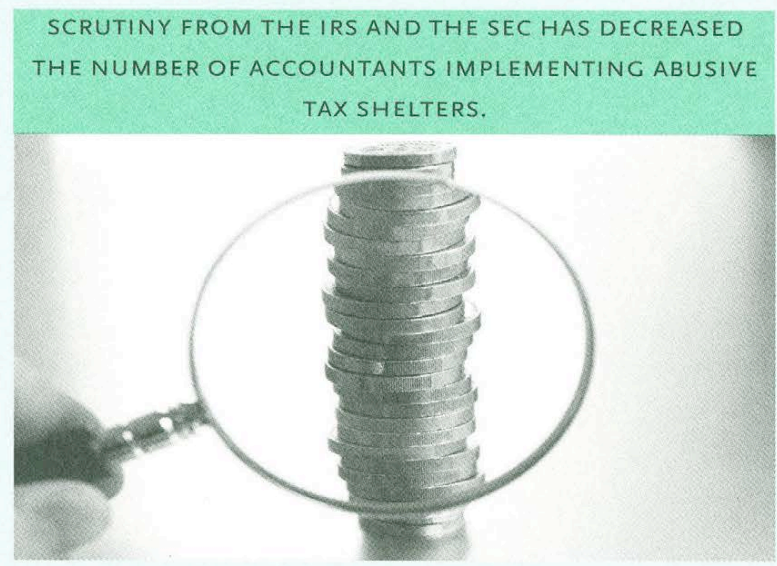


In researching and analyzing the role of the professional in the tax shelter industry, two common threads became apparent. First, there is an obvious conflict of interest present when auditors and accountants develop and market tax shelter strategies. The important principle of independence, which is mandated in a CPA's practice, is compromised through the provision of tax advice in an auditing engagement. This is why the PCAOB adopted new auditor independence rules that constrain firms' participation in selling tax shelters to clients. ${ }^{\text {xxvi }}$ If the client being provided tax shelter advice is a non-audit client, then this standard of independence may not be compromised. However, attorneys are legally not allowed to practice law if they are an employee of an accounting firm. This is an important distinction as it elucidates the assumption that tax advisory services from a public accounting firm should only be provided by accountants working for a non-audit client. I believe that this assumption, however, is also incorrect. As one interviewee noted, "the gray areas of unintended tax shelters are subject to legal interpretation and not accounting interpretation. I don't see how you can issue a tax opinion without practicing law."xxxvii Since "opinion letters are the stock in trade of tax lawyers," xxxviii tax shelter work seems to be a function of legal advisory rather than of accountants' recommendations.

The second ostensible common thread involves the concept of legal privilege. In the legal industry, attorney-client privilege is one of the most sacred professional principles. If compromised, this breach of privilege can result in attorneys losing their licenses to practice law. Because accountants do not maintain this same level of privilege, they are more at risk to compromise their duties as professionals with respect to the confidentiality and privacy of tax shelter information. Therefore, lawyers have more extensive access to documents used in the analysis of tax laws. In this way, lawyers are better positioned to provide tax shelter advisory services that comply with IRS and other external regulations.

The final and possibly most important issue for profession- als is the pricing of tax services. Before the explosion of litigation and governmental regulation related to abusive tax shelters in the early 2000 s, many professionals assessed fees on a contingency basis. For instance, a group of KPMG tax professionals collected Io percent of the tax loss claimed for each tax shelter transaction. ${ }^{\text {xxxix }}$ This type of pricing is blatantly unethical and unprofessional and is no longer used in practice. Aggressive pricing policies like those used by many KPMG professionals engendered many of the psychological forces which drove the growth in abusive tax shelters. Essentially, professionals are more likely to market their own products, even if they do not think that they will pass statutory muster, if fees are on a contingent basis.

In the current environment, tax professionals bill their tax shelter work on an hourly basis. This pricing policy provides a fairer estimate of the professional's actual work output and negates the psychological bias that pervaded tax professionals in previous years. Also, service prices are more closely correlated to the professional's legal opinion of the transaction. As one interviewee stated, "lawyers are needed to provide independent opinions of risk and assurance levels. Lawyers have in this sense become risk management experts with respect to tax shelters." $x$ Because fees are closely correlated to the legal risk inherent to the transaction, lawyers' fees for advice regarding unintended shelters are higher than for advice regarding intended tax shelters. Lawyers are careful to point out, however, that this form of pricing is not meant to encourage "pushing the envelope" with tax shelter advice. Rather, it is meant to reflect the fact that unintended tax shelters require more legal analysis and research than intended tax shelters, which are more easily comprehended and implemented. Hence, lawyers expend more time and effort working on the interpretation of unintended tax shelters and consequently earn more for this type of work. From the client's point of view, there is a risk/reward proposition for every tax shelter product. Economically, then, clients' willingness to pay higher prices should and does increase proportionately to the risk of the tax shelter transaction. 


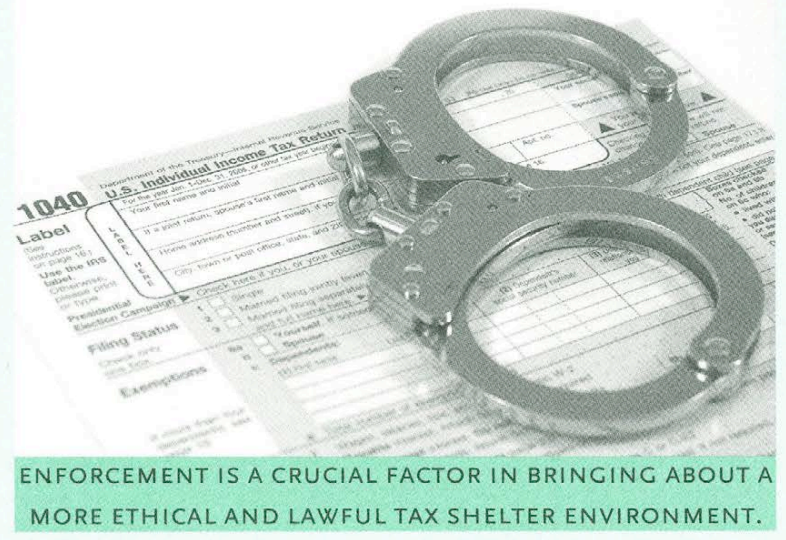

POSSIBLE FUTURE SOLUTIONS

The future of abusive tax shelters will be primarily determined by the efficiency and competence of the IRS's enforcement. As my interviewees have echoed, the legislation currently in place is more than sufficient to curtail the usage of abusive tax shelters. The IRS, SEC, and the government in general will simply not be able to correct all of the loopholes in our complex tax code through continued legislation. As one interviewee affirmed, "there will always be financial engineers out there who are creating intricate, exotic tax shelter products."xli Intensified enforcement of the disclosure and registration requirements, greater monitoring of the tax shelter industry as a whole, and continued judicial reliance on the doctrine of economic substance should produce a more ethical system. This structure will hopefully allow advisors (accountants and lawyers) and clients (companies using the tax shelters) to more easily identify potentially abusive tax shelters and to reject such transactions.

The IRS's level of enforcement will be the most critical factor in creating a more ethical and lawful tax shelter environment. In the I970s, the IRS conducted a drastic reduction in its enforcement workforce. The aim of this business decision was to cut costs and improve revenues in the short term. Since the use of abusive tax shelters was still in its nascent phases then, this action seemed logical. However, the IRS did not anticipate the monstrous long-term costs of reducing its enforcement powers so radically. The IRS did not return to its pre-reduction enforcement workforce levels until the early 2000 s. It has been argued, therefore, that the IRS's economically rational decision in the I970s cost our country (the Treasury) tens of billions of dollars in taxes. As a result of this realization, many states have begun to increase funding and workforce levels for tax enforcement. Earlier this year, for example, California governor Arnold Schwarzenegger mandated the hiring of 500 new tax collectors and investigators in an effort to close California's $\$ 6.5$ billion tax gap. ${ }^{\text {xlii }}$ Advanced enforcement measures such as these must be implemented in order to effectively reinforce the regulatory restrictions created by the IRS and the government.

Another suggestion would be to establish more uniformity among statutory and international tax laws. As aforementioned, many unintended (and potentially abusive) tax shelters are part of inter-jurisdictional transactions. Creating greater uniformity among tax statutes and regulations would largely counteract the financial incentives engendered by disparate statutory regulations. This action would significantly curb the use of inter-jurisdictional tax shelters, and therefore inherently reduce the usage of abusive tax shelters. As in the accounting world, all stakeholders involved will be better served if tax laws and regulations are comparable and understandable across jurisdictions. ${ }^{x l i i i}$

A third solution which may aid the IRS in targeting abusive tax shelters would be to improve information flow among state tax organizations and the IRS. In addition to strengthening the power of the disclosure and registration requirements, this improvement would widen the IRS's awareness of the countless types of abusive tax shelters. Enhancing information flow would also provide better accuracy with respect to the IRS's understanding of the location of abusive tax shelter activity. From this point of view, the IRS could more precisely delegate enforcement powers to state authorities who are more familiar with their individual tax jurisdictions than federal officials. Additionally, there must be more exchange between institutional 
representatives of tax professionals, such as the AICPA and the American Bar Association, and the IRS. Improved relations and discussion between these two organizations will positively impact the tax shelter industry; if the relationship between the two sides is stronger, then the internal and external pressures on tax professionals will increase. The ethical disincentives fostered by such pressure will help to constrain abusive tax shelter activity.

Although tax planning will probably always be offered as a service by public accounting firms, I believe that the provision of tax shelter advisory should only be undertaken by attorneys working for law firms. In complement to the earlier discussion, the determination of whether a tax shelter is legal or illegal can only be made by lawyers, since tax shelters are ultimately the product of the interpretation of tax law. As such, lawyers are most aptly positioned to render ethical and legal tax shelter advice to clients.

The pricing structure for tax services is also an integral issue that will have important implications on the tax shelter industry for many years. It is obvious that the old practice of earning contingent fees based on tax losses claimed is unethical and unconscionable. The current method of pricing, in which professionals bill at an hourly rate just as if they were providing auditing services, is the most accurate and ethical pricing method. Because the amount of a professional's time spent on tax shelter interpretation is closely correlated to the difficulty and client risk inherent in a transaction, this pricing structure is an earnest compensation measure for professionals and should be used for all tax shelter advisory work.

On a macro level, in the long-term, the tax shelter industry must move towards a principles-based system and away from the current, overly rules-based system. In the accounting industry, this change is already underway. Lawyers and other tax professionals are hired and respected for their professional judgment abilities. If our nation excessively restricts this judgment, then it will actually hurt our economy. It is intuitive that "the more detail that is re- quired, the less room there is for judgment . . . rules increase complexity and actually can decrease the meaningfulness of information." xliv A principles-based system would allow more room for professional judgment and also diminish the complexity of our tax system. In turn, our nation's courts would not be overburdened with unnecessary interpretation of convoluted tax rules; rather, the courts would establish principal guidelines (such as the economic substance doctrine) which would allow tax professionals to more easily evaluate the legality and legitimacy of tax shelter transactions. As the CEOs of the "Big 6" elucidated, "one of the most important lessons from the recent spate of financial reporting scandals is that the world's complex business transactions cannot be communicated through proscriptive rules: clarity relies on adhering to sound principles applied with expert judgment."xlv The tax industry must therefore follow its brother, the auditing industry, into a principles-based future.

\section{ENDNOTES}

i. Merriam Webster Online Dictionary

ii. "Overview and History of Tax Shelters" (2008)

iii. "The Legislative History of Abusive Tax Shelters" (2005)

iv. IRC Section 6III

v. IRC Section 6112

vi. "The Legislative History of Abusive Tax Shelters" (2005)

vii. "The Legislative History of Abusive Tax Shelters" (2005)

viii. Joint Committee on Taxation-Penalty Study

ix. JCT Examination of Abusive Tax Shelters-JCX 84-99

x. Treasury White Paper on Corporate Tax Shelters

xi. Treasury Penalty Study on Corporate Tax Shelters

xii. Interviewee B

xiii. IRS Announcement 2000-12

xiv. IRS Announcement 2000-51

xv. "The Legislative History of Abusive Tax Shelters" (2005)

xvi. All interviewees espoused this opinion.

xvii. Gregory v. Helvering (I935)

xviii. Salsman (2002)

xix. Gregory v. Helvering (I935)

xx. Long-Term Capital Holdings v. United States of America (2005)

xxi. Keinan (2006)

xxii. Keinan (2006)

xxiii. Hilton (2008)

xxiv. Beale (2006)

xxv. Rostain (2006)

xxvi. Rostain (2006)

xxvii. Interviewees $A$ and $B$ 
xxviii. Rostain (2006)

xxix. Interviewee A

xxx. Container Corp. v. Franchise Tax Board (I983)

xxxi. Interviewee C

xxxii. Interviewee C

xxxiii. All interviewees espoused this opinion.

xxxiv. Interviewees $A$ and $B$

xxxv. Interviewee A

xxxvi. Rostain (2006)

xxxvii. Interviewee A

xxxviii. Interviewee A

xxxix. Rostain (2006)

xl. Interviewee A

xli. Interviewee A

xlii. Sheppard (2008)

xliii. DiPiazza (2006

xliv. DiPiazza (2006)

xlv. DiPiazza (2006)

\section{REFERENCES}

Beale, Leslie. "Glaxo Transfer Pricing Settlement," A Taxing Matter.

http://ataxingmatter.blogs.com/tax/2006/09/glaxo_transfer_. $\mathrm{html}$. Accessed II September 2006

CMA Consolidated Inc. v. Comissioner, 89 T.C.M. (CCH) 70I, 2005 Tax. Ct. Memo LEXIS 16.

Container Corp. v. Franchise Tax Board, 463 U.S. 159 (1983).

DiPiazza, Samuel, et al. "Global Capital Markets and the Global Economy: A View from the CEO's of the International Audit Networks." Global Public Policy Symposium. November 2006.

Gregory v. Helvering. 69 F.2d 809, 810 (2d Cir. 1934), aff'd, 293 U.S. 465,55 S.Ct. 266,79 L.Ed. 596 (1935)

Hilton, Ronald. 2008. Managerial Accounting. $7^{\text {th }}$ ed. New York: McGraw-Hill/Irwin.

\section{I.R.C $\int 6 \mathrm{II2}$}

I.R.C. $\int$ GII.

Interviewee A. April 2, 2008

Interviewee B. April 4, 2008

Interviewee C. April 2, 2008

IRS Announcement 2000-I2.

IRS Announcement 2000-5I.
Joint Committee on Taxation, Special Tax Penalty Study. June 1999 .

Joint Committee on Taxation-Examination of Abusive Tax Shelters-JCX 84-99. July 1999.

Keinan, Yoram. 2006. Playing the Audit Lottery: The Role of Penalties in the U.S. Tax Law in the Aftermath of Long Term Capital Holdings v. United States, 3 Berkeley Bus. L.J. 38I.

Long Term Capital Holdings LP v. United States, I50 Fed. App'x 40 (2d Cir. 2005)

"Overview and History of Tax Shelters." Tax Shelter Lawsuits. 2008. http://www.tax-shelter-

lawsuits.com/pages/overview.html.

Penalty Study on Corporate Tax Shelters. October I999. U.S. Treasury Department.

Quill Corp.v. North Dakota, (9I-oI94), 504 U.S. 298 (1992).

Rostain, Tanina. 2006. "Travails in Tax: KPMG and the TaxShelter Controversy." Legal Ethics: Law Stories. Ed. Rhode, Deborah and Luban, David. New York. Chapter 3.

Salsman, Richard. "Treasury Secretary Paul O'Neil Confuses Tax Avoidance versus Tax Evasion." Capitalism Magazine. I3 September 2002. http://www.capmag.com/article.asp?ID= I856. Accessed 4 April 2008.

Santa Monica Pictures, LLC. v. Commissioner, 98 T.C.M. (CCH) II 57 (2005)

Sheppard, Harrison. "Schwarzenegger Targets Tax Cheats." The Mercury News Online. http://www.mercurynews.com/localnewsheadlines/ci_8228577? nclick_check=I. Accessed II February 2008

"Tax Shelters." Merriam-Webster Online Dictionary. http://www.merriam-webster.com/dictionary/Tax\%20Shelters. Accessed 4 April 2008.

"The Legislative History of Abusive Tax Shelters." 2005. Abusive Tax Shelter History. Internal Revenue Service, http://www.irs.gov/pub/irs-utl/i.b_-_history_of_shelters.pdf.

White Paper on Corporate Tax Shelters. .July I999 U.S. Treasury Department. 